\title{
Competition-function tradeoffs in ectomycorrhizal fungi
}

\author{
Holly V Moeller ${ }^{\text {Corresp., }}{ }^{1,2}$, Kabir G Peay $^{3}$ \\ ${ }^{1}$ Biology Department, Woods Hole Oceanographic Institution, Woods Hole, MA, USA \\ 2 \\ 3 Department of Biology, Stanford University, Stanford, California, United States \\ Corresponding Author: Holly V Moeller \\ Email address: hollyvm@alumni.stanford.edu
}

Background. The extent to which ectomycorrhizal fungi mediate primary production, carbon storage, and nutrient remineralization in terrestrial ecosystems depends upon fungal community composition. However, the factors that govern community composition at the root system scale are not wellunderstood. Here, we explore a potential tradeoff between ectomycorrhizal fungal competitive ability and enzymatic function.

Methods. We grew Pinus muricata (Bishop Pine) seedlings in association with ectomycorrhizal fungi from three different genera in a fully factorial experimental design. We measured seedling growth responses, ectomycorrhizal abundance, and the root tip activity of five different extracellular enzymes involved in the mobilization of carbon and phosphorus.

Results. We found an inverse relationship between competitiveness, quantified based on relative colonization levels, and enzymatic activity. Specifically, Thelephora terrestris, the dominant fungus, had the lowest enzyme activity levels, while Suillus pungens, the least dominant fungus, had the highest.

Discussion. Our results identify a tradeoff between competition and function in ectomycorrhizal fungi, perhaps mediated by the competing energetic demands associated with competitive interactions and enzymatic production. These data suggest that mechanisms such as active partner maintenance by host trees may be important to maintaining "high-quality" ectomycorrhizal fungal partners in natural systems. 


\section{Competition-function tradeoffs in ectomycorrhizal fungi}

$4 \quad$ Holly V. Moeller ${ }^{*}$ and Kabir G. Peay ${ }^{2}$

6

${ }^{1}$ Biology Department, Woods Hole Oceanographic Institution, 266 Woods Hole Road, Woods

8 Hole, MA 02543

${ }^{2}$ Department of Biology, Stanford University, 371 Serra Mall, Stanford, CA 94305

10

*Corresponding Author: hollyvm@alumni.stanford.edu, +1 508 289-3819, Woods Hole

12 Oceanographic Institution, 266 Woods Hole Road, Mail Stop 52, Woods Hole, MA 02543

Running Head: Competition vs. function in ectomycorrhizae 
24 Abstract:

Background. The extent to which ectomycorrhizal fungi mediate primary production, carbon

26 storage, and nutrient remineralization in terrestrial ecosystems depends upon fungal community composition. However, the factors that govern community composition at the root system scale

28 are not well-understood. Here, we explore a potential tradeoff between ectomycorrhizal fungal competitive ability and enzymatic function.

30 Methods. We grew Pinus muricata (Bishop Pine) seedlings in association with ectomycorrhizal fungi from three different genera in a fully factorial experimental design. We measured seedling

32 growth responses, ectomycorrhizal abundance, and the root tip activity of five different extracellular enzymes involved in the mobilization of carbon and phosphorus.

34 Results. We found an inverse relationship between competitiveness, quantified based on relative colonization levels, and enzymatic activity. Specifically, Thelephora terrestris, the dominant

36 fungus, had the lowest enzyme activity levels, while Suillus pungens, the least dominant fungus, had the highest.

38 Discussion. Our results identify a tradeoff between competition and function in ectomycorrhizal fungi, perhaps mediated by the competing energetic demands associated with competitive

40 interactions and enzymatic production. These data suggest that mechanisms such as active partner maintenance by host trees may be important to maintaining "high-quality"

42 ectomycorrhizal fungal partners in natural systems. 


\section{Introduction}

Ectomycorrhizal fungi (EMF), the belowground mutualistic partners of most of the world's temperate tree species, are key regulators of primary production and nutrient

46 remineralization in terrestrial ecosystems. EMF mediate the transfer of water and nutrients from the soil to their host trees (Brownlee et al., 1983; Leake et al., 2004) and serve as a pathway for

48 photosynthetically fixed carbon into the soil community (Talbot, Allison \& Treseder, 2008).

These fungi also affect the extent of carbon storage (Averill, Turner \& Finzi, 2014; Clemmensen et al., 2015) and the rate of nutrient cycling (Leake et al., 2004; Koide, Fernandez \& Malcolm, 2014) belowground.

The species composition of EMF communities affects these functions. For example, some taxa utilize distinct foraging strategies, such as the formation of rhizomorphs which allow

54 the transport of water and nutrients over long distances (Brownlee et al., 1983; Agerer, 2001; 2006), accumulate relatively high amounts of mycelial biomass belowground (Hobbie, 2006),

56 and are linked with efficient nitrogen mobilization and low carbon sequestration (Clemmensen et al., 2015). EMF that form melanized hyphae may be more tolerant of water stress (Fernandez \&

58 Koide, 2013) and resistant to decomposition (Fernandez \& Koide, 2014; Koide, Fernandez \& Malcolm, 2014) than other taxa. EMF also differ in the extent to which they produce

60 extracellular enzymes that break down soil organic matter and release nitrogen and phosphorus (Courty et al., 2006; Courty, Franc \& Garbaye, 2010; Jones et al., 2010; Tedersoo et al., 2012).

62 Because fungal traits are linked through their function to ecosystem processes (Koide, Fernandez \& Malcolm, 2014; Treseder \& Lennon, 2015), understanding the factors controlling

64 ectomycorrhizal community composition on host tree root systems is of major importance. 
While both abiotic (e.g., edaphic environment (Moeller, Peay \& Fukami, 2014)) and

66 biotic (e.g., plant community context (Bogar \& Kennedy, 2013; Moeller et al., 2015)) conditions may play a primary role in filtering members of the ectomycorrhizal community, recent work has

68 highlighted the importance of fungal species interactions to ectomycorrhizal community assembly (Kennedy, 2010). Competitive interactions, in particular, may locally structure fungal

70 communities within a host plant's root system, leading to competitive exclusion (Villeneuve, Le Tacon \& Bouchard, 1991; Kennedy \& Bruns, 2005; Kennedy, Peay \& Bruns, 2009) or spatial

72 segregation (Taylor \& Bruns, 1999; Pickles et al., 2012). Over longer time scales, such competitive interactions may contribute to the successional patterns observed within

74 ectomycorrhizal communities (Mason et al., 1983; Visser, 1995; Nara et al., 2003), likely in part through a tradeoff between colonization and competitive abilities (Lilleskov \& Bruns, 2003;

76 Kennedy et al., 2011).

Some functional traits such as foraging type (Peay, Kennedy \& Bruns, 2011;

78 Clemmensen et al., 2015) and propagule persistence (Baar et al., 1999; Taylor \& Bruns, 1999) are associated with successional stage; however, it is not clear whether these differences in

80 functionality result in differing competitive abilities. Here, we tested for a tradeoff between competitiveness and nutrient acquisition ability (measured as enzymatic activity) across three

82 different ectomycorrhizal fungal genera. By holding host tree age, inoculum potential, and environmental conditions constant, we experimentally tested three hypotheses.

84 First, we hypothesized that a dominance hierarchy exists among the three fungal taxa used in our study, Rhizopogon occidentalis, Suillus pungens, and Thelephora terrestris. Based on 86 prior greenhouse experimental work, we expected $R$. occidentalis to be competitively dominant to $S$. pungens (Kennedy et al., 2007; 2011), and we expected $T$. terrestris, an aggressive seedling 
88 colonizer (Mason et al., 1983; Velmala et al., 2013), to be competitively dominant to both these species. Second, we expected this dominance hierarchy to be inversely related to fungal

90 enzymatic function. We based this hypothesis on the rationale that fungi experience an energetic tradeoff: they can either produce metabolically costly extracellular enzymes, or they can invest in

92 chemical defenses against their competitors. Third, we hypothesized that this tradeoff would impact host tree seedling growth: Seedlings would accrue the highest biomass when associating

94 with the least dominant, most highly enzymatically functional fungi.

\section{Materials and Methods}

\section{Experimental design}

98 We worked with Pinus muricata (Bishop Pine) and three ectomycorrhizal fungi (Rhizopogon occidentalis, Suillus pungens, and Thelephora terrestris) known to associate with this tree in its

100 native range (Peay et al., 2007). We selected these fungi because they are among the most common and abundant in early successional pine forests in Point Reyes National Seashore

102 (PRNS), where we worked (Peay et al., 2007). We tested the competitive abilities, enzyme expression levels, and effects on seedling growth of these fungi grown in isolation and in

104 competition.

P. muricata seeds were obtained from PRNS. Prior to the start of the experiment, seeds

106 were surface sterilized and germinated in autoclave-sterilized perlite. Within 7 days, germinated seedlings were transplanted into conetainers filled with a 50:50 mix of autoclaved sand and soil

108 from PRNS. Spores from each of the three EMF were obtained from sporocarps collected at PRNS. Sporocarps were incubated spore-side down overnight on foil at room temperature.

110 Spores were collected by washing the foil with sterile (distilled, autoclaved) water and 
refrigerated at $4^{\circ} \mathrm{C}$ for three weeks until inoculation. Prior to inoculation, hemocytometer counts

112 followed by serial dilutions in sterile water were used to obtain a concentration of 1000 spores per $\mathrm{mL}$ for each of the three fungal species. We did not conduct spore viability stain assays;

114 however, spore storage time was short (Bruns et al., 2009), and handling was consistent with other studies using spore inoculum from these species (Kennedy \& Bruns, 2005; Kennedy \&

116 Peay, 2007; Kennedy, Peay \& Bruns, 2009; Peay et al., 2012), so we expected a high proportion of viable spores in the inoculation slurries.

118 We inoculated the $P$. muricata seedlings with zero, one, two, or three fungal species in all possible combinations. We randomly assigned five seedlings to each treatment group (for a total

120 of 5 seedlings $\mathrm{x} 7$ treatments +1 control $=40$ seedlings $)$. Each seedling received a total of 3-mL of inoculum. For control (non-mycorrhizal) seedlings, this consisted of 3-mL of sterile water.

122 Seedlings inoculated with EMF received 1-mL of inoculum per fungal species (so that seedlings in the single-fungus treatments received $1-\mathrm{mL}$ of spore inoculum and $2-\mathrm{mL}$ of distilled water).

124 Thus, seedlings in the three-species treatment received a total of 3000 spores (1000 per species).

Seedlings were maintained in a greenhouse at Stanford University for five months

126 between inoculation and harvest. This experimental duration was chosen because it approximates the length of the main growth and fruiting season of EMF in PRNS, and because previous

128 greenhouse studies of $P$. muricata seedlings and their EMF have been of similar duration (Kennedy \& Bruns, 2005; Kennedy \& Peay, 2007; Peay, Garbelotto \& Bruns, 2009; Kennedy,

130 Peay \& Bruns, 2009). At harvest, each seedling's root system was separated from the shoot at the root collar. The root system was washed clear of adhering soil using tap water. Roots were then

132 cut into 3-cm segments, homogenized, and a subset was examined under a dissecting microscope. This entire subset was scored for mycorrhization using the grid-line intersection 
134 method: root segments were randomly arranged over a 1-cm grid, and every grid crossing was scored as mycorrhizal or non-mycorrhizal based on the presence or absence of fungal hyphae

136 (Giovannetti \& Mosse, 1980). Note that, because not all of the root system is comprised of fine root tips, total mycorrhization levels are always $<100 \%$. Following examination, eight

138 mycorrhizal root tips from each seedling were randomly selected for fungal identification, and ten mycorrhizal tips were selected for enzyme assays. Enzyme assay tips were also collected

140 from control seedlings to establish non-mycorrhizal baseline activity levels. Following root system processing, seedling root systems and shoots were dried at $65^{\circ} \mathrm{C}$ for 48 hours and then

142 weighed to determine biomass.

\section{$144 \quad$ Fungal identification and enzyme assays}

We used Sanger sequencing to assign mycorrhizal root tips to species. To extract DNA, tips were

146 heated in 10 $\mu \mathrm{L}$ Extraction Solution (SKU E7526; Sigma-Aldrich Co. LLC, St. Louis, MO) for $10 \mathrm{~min}$ at $65^{\circ} \mathrm{C}$, then $10 \mathrm{~min}$ at $95^{\circ} \mathrm{C}$, before addition of $10 \mu \mathrm{L}$ of Neutralization Solu- tion B

148 (SKU N3910; Sigma-Aldrich Co. LLC). The internal transcribed spacer (ITS) region of the nuclear ribosomal RNA genes of each root tip was amplified using the ITS-1F (Gardes \& Bruns,

150 1993) and ITS-4 primers (White et al., 1990) and sequenced by Beckman Coulter Genomics (Danvers, MA). The resultant sequences were assigned to one of the three species using the

152 Basic Local Alignment Search Tool (BLAST, http://blast.ncbi.nlm.nih.gov).

We used fluorimetric assays to quantify the activity levels of five different enzymes: $\alpha$ -

154 glucosidase (which hydrolyzes starch and glycogen), $\beta$-glucosidase (which hydrolyzes cellobiose), N-acetyl-glucosaminidase (which breaks down chitin), $\beta$-xylosidase (which breaks

156 down xylose), and acid phosphatase (which releases phosphate). Each root tip was placed in an 
individual well of a 96-well-screen-bottom plate, and enzyme activities were sequentially

158 measured according to the protocol outlined in Pritsch et al. (2011). Total per-tip activity was calculated based on a standard curve using 4-methylumbelliferone, and normalized to surface

160 area calculated using WinRHIZO. Following enzyme assays, DNA was also extracted from these tips, amplified, sequenced, and used either to assign root tips to a fungal taxon or to confirm lack

162 of mycorrhization in the controls.

\section{Data analysis}

We used single-species treatments to verify the viability of our spore inoculum. In multi-species

166 treatments, we determined the competitively dominant fungus as the one with the greatest relative colonization (i.e., greatest proportion of sequences in our randomly selected set of root

168 tips). To determine differences in enzyme activity and seedling growth, we compared treatment means using Tukey's Honestly Significant Difference tests to correct for multiple hypothesis

170 testing. All statistical calculations were performed using R (R Core Team, 2014). To quantify variance in enzymatic activity, we used a principal components analysis to compress data from

172 all five enzymatic assays into two dimensions for visualization (package bpca; (Faria, Demetrio \& Allaman, 2016)). We then computed the Euclidean distance between pairs of tips from the 174 same treatments (vegan, function betadisper; (Oksanen et al., 2013)) and performed a Tukey's Honestly Significant Difference test to compare within-treatment variance.

\section{Results}

Fungal mycorrhization levels. In single-species treatments, all fungi established associations with P. muricata seedlings. Mycorrhization levels differed by fungal taxon (Figure 
180 1). Thelephora terrestris had the highest mycorrhization level of $68.2+/-0.00159 \%$ (mean $+/-$ standard deviation) root length colonized. Rhizopogon occidentalis $(23.5+/-0.0952 \%)$ and Suillus

182 pungens $(27.6+/-15.6 \%)$ were similar to one another in abundance. No ectomycorrhizal fungi were detected on the control seedlings.

Hypothesis 1: Dominance hierarchy. Our data supported our hypothesized dominance hierarchy: T. terrestris competively excluded both $R$. occidentalis and $S$. pungens. $R$.

186 occidentalis was competitively dominant (in terms of root mycorrhization) to, but did not completely exclude, S. pungens in the two-species treatment containing these fungi (Figure 1). Hypothesis 2: Dominance-function tradeoff. Enzyme profiles from single-species treatments supported our hypothesis that the least competitive fungus, $S$. pungens, would have

190 the highest enzyme activity levels. S. pungens enzymatic activity was higher than nonmycorrhizal control root tips for all five extracellular enzymes assayed (Figure 2, yellow bars).

192 In contrast, T. terrestris, the competitively dominant fungus, had enzymatic activity levels indistinguishable from controls (Figure 2, blue bars), and R. occidentalis, of intermediate

194 competitive ability, had elevated enzymatic activity levels only for $\alpha$ - and $\beta$-glucosidase and Nacetyl-glucosaminidase (Figure 2, red bars). Fungi varied significantly in their overall enzymatic

196 profiles (Figure 2f, Table 1; see Supplemental Figure 1 for additional PCA axes). Variance in enzymatic activity was greatest for S. pungens, intermediate for $R$. occidentalis, and lowest

198 (equivalent to control tips) for T. terrestris (Figure 3). In multi-species treatments, $\beta$-Xylosidase and Acid Phosphatase expression levels were elevated for T. terrestris-infected tips (Figure 4). Hypothesis 3: Seedling growth response. Seedling aboveground, belowground, and total biomass did not differ by treatment; thus our third hypothesis was not supported. Overall, we did 202 observe a positive relationship between mycorrhization level and seedling biomass (Figure 5). 
204 Discussion

In this study, we present an experimental test for competition-function tradeoffs across three

206 genera of ectomycorrhizal fungi (EMF). We observed a clear competitive dominance hierarchy among the EMF that was inversely related to their extracellular enzymatic activities.

208 Specifically, the most competitively dominant EMF, Thelephora terrestris, had enzymatic activities indistinguishable from non-mycorrhized tree roots, whereas the competitively inferior

210 Suillus pungens exhibited elevated enzymatic activity across all five enzymes assayed. A number of studies have previously documented differences in enzymatic activity profiles across (Courty

212 et al., 2005; 2006; Buée et al., 2007; Courty, Franc \& Garbaye, 2010; Kipfer et al., 2012;

Velmala et al., 2013; Walker, Ward \& Jones, 2015) and within (Jones et al., 2010) fungal genera.

214 These differences, especially when observed in the field among members of assembled EMF communities, are suggestive of functional complementarity (Courty et al., 2005; Buée et al.,

216 2007; Jones et al., 2010). In some cases, e.g., Rhizopogon species, enzymatic activities are disproportionately high relative to species abundance (Walker et al., 2014). However, to our

218 knowledge, this study is the first to experimentally link these differences in enzymatic activity with competitive ability. Because our study, like others that quantify species-specific enzymatic

220 activity, used root tips to obtain fungal tissues, our enzymatic data are representative only of root-tip associated exoenzyme activities, which may be different than expression levels in other

222 parts of the soil (e.g., at the edges of hyphal extent furthest from the host tree where fungi are foraging for nutrients, or at local hotspots of resource availability in the heterogeneous soil

224 environment) (Wright et al., 2005; Liao et al., 2014). Thus, much work remains to be done to determine the whole organism's functional potential. 
That $T$. terrestris was the most competitively dominant EMF in our study was not surprising given its proclivity for vigorous growth under greenhouse conditions (Mason et al.,

228 1983; Velmala et al., 2013). However, S. pungens and R. occidentalis are key community members on Pinus muricata in the field, including at Point Reyes National Seashore where the

230 seeds, soils, and fungal spores used in this study were collected (Peay et al., 2007). All three species are capable of colonizing seedlings through spore dispersal, with $S$. pungens and $R$.

232 occidentalis more consistently observed on small tree islands than T. terrestris (Peay et al. 2007). R. occidentalis colonizes through generation of a long-lived spore bank (Bruns et al. 2009),

234 while $S$. pungens and T. terrestris are the two most prolific aerial spore dispersers in the system (Peay et al. 2012). Our competitive dominance hierarchy, which is the inverse of this dispersal

236 hierarchy, suggests a competition-colonization tradeoff among these taxa similar to that observed by Kennedy et al. (2011), at least in terms of root system abundance. While EMF may compete

238 in other ways, such as by competing for nutrient and water resources in the soil or by competing for plant carbon resources (delivery of which may vary by root tip occupancy), in this case the

240 observed complete exclusion of other EMF by T. terrestris suggests strong competitive dominance. However, in cases where exclusion is incomplete measurements of carbon and

242 nitrogen acquisition may be necessary to determine competitive dominance. Although competitively excluded from seedling root systems by T. terrestris in our study, the persistence

244 of S. pungens and R. occidentalis in the field (at least through the first decade of succession) could be the result of several mechanisms. First, less competitive fungi may be maintained 246 through active partner maintenance. This could be the case if trees allocate carbon to their fungal partners in proportion to their partners' provision of resources (Hoeksema \& Kummel, 2003), 248 which would likely be greater for highly enzymatically active EMF like S. pungens. Second, 
trees with larger root systems are likely to support a greater diversity of EMF than the seedlings

250 in our study (Nara et al., 2003). Third, competition among EMF can be context dependent (Kennedy, Peay \& Bruns, 2009), and while T. terrestris is dominant under greenhouse

252 conditions, this is unlikely to be the case for all biotic and abiotic conditions.

Greenhouse growth conditions may also be responsible for the homogeneity of the

254 seedling growth response. Although Kipfer et al. (2012) found that the most enzymatically active fungus in their study, Suillus granulatus, had a positive effect on seedling growth, we did not

256 observe statistically significant differences in growth by treatment in our study. In part, this was likely due to the homogeneous, high-quality soil environment created by autoclaving the

258 experimental soils, which can release substantial amounts of nutrients into plant-accessible pools, reducing the impact of EMF on seedling growth (Peay, Bruns \& Garbelotto, 2010) and

260 plant carbon allocation to EMF (Hobbie, 2006). Other studies have found no relationship between EMF competitiveness and seedling growth (Kennedy, Peay \& Bruns, 2009). Perhaps, at

262 least at the early seedling stage, growth effects are obscured by conflicting mechanisms. "Highquality" partners like $S$. pungens may be more expensive thanks to the energetic demands of

264 producing extracellular enzymes; this additional carbon cost may negate any benefits to the host seedling, particularly in nutrient-rich soils.

266 Although T. terrestris was the only fungus observed by harvest time in all treatments that included it as a source of inoculum, we did observe reductions in its mycorrhization level and

268 increases in some of its enzymatic activities in multi-species treatments relative to monoculture. These differences may be due to a time lag in competitive displacement of $R$. occidentalis similar

270 to that observed by Lilleskov and Bruns (2003) when R. occidentalis was in competition with Tomentella sublilacina (like T. terrestris, a member of the Thelephoraceae), and/or shifts in $T$. 
272 terrestris enzymatic function induced by the presence of other EMF. Further experimental manipulation of community composition is likely to elucidate the roles of such mechanisms and

274 clarify the role of fungal identity in mutualism function.

We also observed differences in absolute mycorrhization levels among the EMF in our

276 single-species treatments. By our metric (percent of total root length colonized), T. terrestris had mycorrhization levels that were almost double those of the other EMF. In part, this may be due

278 to different root growth forms associated with R. occidentalis and S. pungens, which tend to induce the production of tightly bunched clusters of root tips (HV Moeller and KG Peay, pers.

280 obs.; see also images in the DEtermination of EctoMYcorrhizae database, http://www.deemy.de/) whose prevalence would be underestimated by our grid-intersect

282 sampling method. In contrast, $T$. terrestris exhibits greater spatial extent along the length of fine roots, and the formation of root tip clusters is not observed. While this difference in

284 mycorrhization may also be due to interspecific differences in spore inoculum viability or rates of vegetative spread across root systems, prior studies have observed similar levels of

286 mycorrhization for the three genera we studied (Browning \& Whitney, 1993; Kennedy \& Bruns, 2005). Indeed, Kennedy \& Bruns (2005) observed $\sim 30 \%$ mycorrhization levels for Rhizopogon

288 species within 2 months of inoculation. The evolutionary and ecological reasons for these differences in colonization strategy remain unclear, but a fuller understanding of EMF spatial 290 extent and enzymatic function beyond the plant's immediate root zone will likely shed light on these questions.

\section{Acknowledgements}


294 The authors thank Jennifer Talbot for assistance in performing the enzymatic assays. We also thank Roger Koide and Peter Avis for thoughtful review of our manuscript. 


\section{References}

Agerer R 2001. Exploration types of ectomycorrhizae. Mycorrhiza 11:107-114.

298 Agerer R 2006. Fungal relationships and structural identity of their ectomycorrhizae. Mycological Progress 5:67-107.

300 Averill C, Turner BL, Finzi AC 2014. Mycorrhiza-mediated competition between plants and decomposers drives soil carbon storage. Nature 505:543-545. DOI: 10.1038/nature12901.

302

Baar J, Horton T, Kretzer AM, Bruns T 1999. Mycorrhizal colonization of Pinus muricata from resistant propagules after a stand-replacing wildfire. New Phytologist 143:409-418.

Bogar LM, Kennedy PG 2013. New wrinkles in an old paradigm: neighborhood effects can modify the structure and specificity of Alnus-associated ectomycorrhizal fungal communities. FEMS Microbiology Ecology 83:767-777. DOI: 10.1111/1574-6941.12032.

Browning M, Whitney RD 1993. Infection of containerized jack pine and black spruce by Laccaria species and Thelephora terrestris and seedling survival and growth after outplanting. Canadian Journal of Forest ... 23:330-333. DOI: 10.1139/x93-046.

Brownlee C, Duddridge JA, Malibari A, Read DJ 1983. The structure and function of mycelial systems of ectomycorrhizal roots with special reference to their role in forming inter-plant connections and providing pathways for assimilate and water transport. Plant and Soil 71:433-443.

Bruns T, Peay K, Boynton P, Grubisha L 2009. Inoculum potential of Rhizopogon spores increases with time over the first $4 \mathrm{yr}$ of a 99-yr spore burial experiment. New Phytologist

\section{$316 \quad 181: 463-470$.}

Buée M, Courty P, Mignot D, Garbaye J 2007. Soil niche effect on species diversity and catabolic activities in an ectomycorrhizal fungal community. Soil Biology and Biochemistry 39:1947-1955.

320 Clemmensen KE, Finlay RD, Dahlberg A, Stenlid J, Wardle DA, Lindahl BD 2015. Carbon sequestration is related to mycorrhizal fungal community shifts during long-term succession in boreal forests. New Phytologist 205:1525-1536. DOI: 10.1111/nph.13208.

Courty P-E, Franc A, Garbaye J 2010. Temporal and functional pattern of secreted enzyme activities in an ectomycorrhizal community. Soil Biology and Biochemistry 42:2022-2025.

Courty P-E, Pouysegur R, Buee M, Garbaye J 2006. Laccase and phosphatase activities of the dominant ectomycorrhizal types in a lowland oak forest. Soil Biology and Biochemistry 38:1219-1222.

328 Courty P-E, Pritsch K, Schloter M, Hartmann A, Garbaye J 2005. Activity profiling of ectomycorrhiza communities in two forest soils using multiple enzymatic tests. New

$330 \quad$ Phytologist 167:309-319. DOI: 10.1111/j.1469-8137.2005.01401.x.

$332 \quad$ Principal Components Analysis.

Fernandez CW, Koide RT 2013. The function of melanin in the ectomycorrhizal fungus Cenococcum geophilum under water stress. Fungal Ecology 6:479-486. DOI: 10.1016/j.funeco.2013.08.004.

Fernandez CW, Koide RT 2014. Initial melanin and nitrogen concentrations control the decomposition of ectomycorrhizal fungal litter. Soil Biology and Biochemistry 77:150-157.

338 DOI: $10.1016 /$ j.soilbio.2014.06.026.

Gardes M, Bruns TD 1993. ITS primers with enhanced specificity for basidiomycetes 340 application to the identification of mycorrhizae and rusts. Molecular Ecology 2:113-118. 
DOI: 10.1111/j.1365-294X.1993.tb00005.x.

342 Giovannetti M, Mosse B 1980. An evaluation of techniques for measuring vesicular arbuscular mycorrhizal infection in roots. New Phytologist 84:489-500.

344 Hobbie EA 2006. Carbon allocation to ectomycorrhizal fungi correlates with belowground allocation in culture studies. ECOLOGY 87:563-569.

346 Hoeksema JD, Kummel M 2003. Ecological Persistence of the Plant-Mycorrhizal Mutualism: A Hypothesis from Species Coexistence Theory. The American Naturalist 162:S40-S50. DOI:

$348 \quad 10.1086 / 378644$.

Jones MD, Twieg BD, Ward V, Barker J, Durall DM, Simard SW 2010. Functional

350 complementarity of Douglas-fir ectomycorrhizas for extracellular enzyme activity after wildfire or clearcut logging. Functional Ecology 24:1139-1151. DOI: 10.1111/j.1365-

352 2435.2010.01699.x.

Kennedy P 2010. Ectomycorrhizal fungi and interspecific competition: species interactions, community structure, coexistence mechanisms, and future research directions. New Phytologist 187:895-910. DOI: 10.1111/j.1469-8137.2010.03399.x.

356 Kennedy PG, Bruns TD 2005. Priority effects determine the outcome of ectomycorrhizal competition between two Rhizopogon species colonizing Pinus muricata seedlings. New Phytologist 166:631-638. DOI: 10.1111/j.1469-8137.2005.01355.x.

Kennedy PG, Peay KG 2007. Different soil moisture conditions change the outcome of the ectomycorrhizal symbiosis betweenRhizopogonspecies andPinus muricata. Plant and Soil 291:155-165.

362 Kennedy PG, Higgins LM, Rogers RH, Weber MG 2011. Colonization-Competition Tradeoffs as a Mechanism Driving Successional Dynamics in Ectomycorrhizal Fungal Communities.

$364 \quad$ PLoS ONE 6:e25126. DOI: 10.1371/journal.pone.0025126.t002.

Kennedy PG, Hortal S, Bergemann SE, Bruns TD 2007. Competitive interactions among three ectomycorrhizal fungi and their relation to host plant performance. Journal of Ecology 95:1338-1345. DOI: 10.1111/j.1365-2745.2007.01306.x.

368 Kennedy PG, Peay KG, Bruns TD 2009. Root tip competition among ectomycorrhizal fungi: are priority effects a rule or an exception? ECOLOGY 90:2098-2107.

Kipfer T, Wohlgemuth T, Van Der Heijden MGA, Ghazoul J, Egli S 2012. Growth Response of Drought-Stressed Pinus sylvestris Seedlings to Single- and Multi-Species Inoculation with Ectomycorrhizal Fungi. PLoS ONE 7:e35275. DOI: 10.1371/journal.pone.0035275.t001.

Koide RT, Fernandez C, Malcolm G 2014. Determining place and process: functional traits of ectomycorrhizal fungi that affect both community structure and ecosystem function. New Phytologist 201:433-439. DOI: 10.1111/nph.12538.

376 Leake J, Johnson D, Donnelly D, Muckle G, Boddy L, Read D 2004. Networks of power and influence: the role of mycorrhizal mycelium in controlling plant communities and agroecosystem functioning. Canadian Journal of Botany 82:1016-1045. DOI: 10.1139/b04060.

380 Liao HL, Chen Y, Bruns TD, Peay KG, Taylor JW, Branco S, Talbot JM, Vilgalys R 2014. Metatranscriptomic analysis of ectomycorrhizal roots reveals genes associated with Piloderma-Pinussymbiosis: improved methodologies for assessing gene expression in situ. Environmental Microbiology 16:3730-3742. DOI: 10.1111/1462-2920.12619. contrasting life history strategies are mediated by addition of organic nutrient patches. New Phytologist 159:141-151. DOI: 10.1046/j.0028-646x.2003.00794.x. 
Mason PA, Wilson J, Last FT, Walker C 1983. The concept of succession in relation to the spread of sheathing mycorrhizal fungi on inoculated tree seedlings growing in unsterile soils. Plant and Soil 71:247-256.

390 Moeller HV, Dickie IA, Peltzer D, Fukami T 2015. Mycorrhizal co-invasion and novel interactions depend on neighborhood context. ECOLOGY 96:2336-2347. DOI: 10.1890/14-

392 2361.1.

Moeller HV, Peay KG, Fukami T 2014. Ectomycorrhizal fungal traits reflect environmental conditions along a coastal California edaphic gradient. FEMS Microbiology Ecology 87:797-806. DOI: 10.1111/1574-6941.12265.

396 Nara K, Nakaya H, Wu B, Zhou Z, Hogetsu T 2003. Underground primary succession of ectomycorrhizal fungi in a volcanic desert on Mount Fuji. New Phytologist 159:743-756.

398 DOI: 10.1046/j.1469-8137.2003.00844.x.

Oksanen J, Blanchet FG, Kindt R, Legendre P, Minchin PR, O'Hara B, Simpson GL, Solymos P,

400

402 Stevens MHH, Wagner H 2013. vegan: Community Ecology Package.

Peay KG, Bruns TD, Garbelotto M 2010. Testing the ecological stability of ectomycorrhizal symbiosis: effects of heat, ash and mycorrhizal colonization on Pinus muricata seedling performance. Plant and Soil 330:291-302. DOI: 10.1007/s11104-009-0200-1.

404

Peay KG, Bruns TD, Kennedy PG, Bergemann SE, Garbelotto M 2007. A strong species-area relationship for eukaryotic soil microbes: island size matters for ectomycorrhizal fungi.

406 Ecology Letters 10:470-480.

Peay KG, Garbelotto M, Bruns TD 2009. Spore heat resistance plays an important role in

408

410

412 disturbance-mediated assemblage shift of ectomycorrhizal fungi colonizing Pinus muricataseedlings. Journal of Ecology 97:537-547. DOI: 10.1111/j.13652745.2009.01489.x.

Peay KG, Kennedy PG, Bruns TD 2011. Rethinking ectomycorrhizal succession: are root density and hyphal exploration types drivers of spatial and temporal zonation? Fungal Ecology 4:233-240. DOI: 10.1016/j.funeco.2010.09.010.

414 Peay KG, SCHUBERT MG, NGUYEN NH, Bruns TD 2012. Measuring ectomycorrhizal fungal dispersal: macroecological patterns driven by microscopic propagules. Molecular Ecology

416 21:4122-4136. DOI: 10.1111/j.1365-294X.2012.05666.x.

Pickles BJ, Genney DR, Anderson IC, Alexander IJ 2012. Spatial analysis of ectomycorrhizal

418 fungi reveals that root tip communities are structured by competitive interactions. Molecular Ecology 21:5110-5123. DOI: 10.1111/j.1365-294X.2012.05739.x.

420 Pritsch K, Courty PE, Churin J-L, Cloutier-Hurteau B, Ali MA, Damon C, Duchemin M, Egli S, Ernst J, Fraissinet-Tachet L, Kuhar F, Legname E, Marmeisse R, Müller A, Nikolova P, Peter M, Plassard C, Richard F, Schloter M, Selosse M-A, Franc A, Garbaye J 2011. Optimized assay and storage conditions for enzyme activity profiling of ectomycorrhizae.

424 Mycorrhiza 21:589-600. DOI: 10.1007/s00572-011-0364-4.

R Core Team 2014. R: A language and environment for statistical computing.

426 Talbot JM, Allison SD, Treseder KK 2008. Decomposers in disguise: mycorrhizal fungi as regulators of soil $\mathrm{C}$ dynamics in ecosystems under global change. Functional Ecology

428 22:955-963. DOI: 10.1111/j.1365-2435.2008.01402.x.

Taylor D, Bruns T 1999. Community structure of ectomycorrhizal fungi in a Pinus muricata

430 forest: minimal overlap between the mature forest and resistant propagule communities. Molecular Ecology 8:1837-1850.

432 Tedersoo L, Naadel T, Bahram M, Pritsch K, Buegger F, Leal M, Kõljalg U, Põldmaa K 2012. 
Enzymatic activities and stable isotope patterns of ectomycorrhizal fungi in relation to phylogeny and exploration types in an afrotropical rain forest. New Phytologist 195:832843. DOI: 10.1111/j.1469-8137.2012.04217.x.

436 Treseder KK, Lennon JT 2015. Fungal Traits That Drive Ecosystem Dynamics on Land. Microbiology and Molecular Biology Reviews 79:243-262. DOI: 10.1128/MMBR.00001-15.

438 Velmala SM, Rajala T, Heinonsalo J, Taylor AFS, Pennanen T 2013. Profiling functions of ectomycorrhizal diversity and root structuring in seedlings of Norway spruce (Picea abies)

$440 \quad$ with fast- and slow-growing phenotypes. New Phytologist 201:610-622. DOI: 10.1111/nph.12542.

442 Villeneuve N, Le Tacon F, Bouchard D 1991. Survival of inoculated Laccaria bicolor in competition with native ectomycorrhizal fungi and effects on the growth of outplanted

$444 \quad$ Douglas-fir seedlings. Plant and Soil 135:95-107.

Visser S 1995. Ectomycorrhizal fungal succession in jack pine stands following wildfire. New 446 Phytologist 129:389-401.

Walker JKM, Cohen H, Higgins LM, Kennedy PG 2014. Testing the link between community 448 structure and function for ectomycorrhizal fungi involved in a global tripartite symbiosis. New Phytologist 202:287-296. DOI: 10.1111/nph.12638.

450 Walker JKM, Ward V, Jones MD 2015. Ectomycorrhizal fungal exoenzyme activity differs on spruce seedlings planted in forests versus clearcuts. Trees: Structure and Function:1-15.

452 DOI: $10.1007 / \mathrm{s} 00468-015-1239-7$.

White TJ, Bruns T, Lee S, Taylor JW 1990. Amplification and direct sequencing of fungal ribosomal RNA genes for phylogenetics. In: Innis MA, Gelfand DH, Sninsky JJ, White TJ eds. PCR protocols: a guide to methods and applications. New York: Academic Press, Inc,

$456 \quad 315-322$.

Wright DP, Johansson T, Le Quéré A, Söderström B, Tunlid A 2005. Spatial patterns of gene expression in the extramatrical mycelium and mycorrhizal root tips formed by the ectomycorrhizal fungus Paxillus involutus in association with birch (Betula pendula) seedlings in soil microcosms. New Phytologist 167:579-596. DOI: 10.1111/j.14698137.2005.01441.x. 
464

Table 1. Principal components analysis of enzymatic activity for single-species treatments.

Principal Component Axis

Percent Explained

Loadings

$\alpha$-glucosidase

$\beta$-glucosidase

$\mathrm{N}$-acetylglucosaminidase

$\beta$-xylosidase

acid phosphatase

$\begin{array}{rrrrr}1 & 2 & 3 & 4 & 5 \\ 79.84 & 14.18 & 4.06 & 1.11 & 0.800 \\ & & & & \\ -6.61 & 1.53 & -2.10 & 0.0609 & 0.775 \\ -6.36 & 2.60 & 1.67 & -0.981 & 0.113 \\ -6.82 & 1.33 & 0.965 & 1.29 & -0.289 \\ -6.77 & -1.60 & -1.19 & -0.437 & -1.01 \\ -5.21 & -4.77 & 0.91 & -0.00634 & 0.568\end{array}$



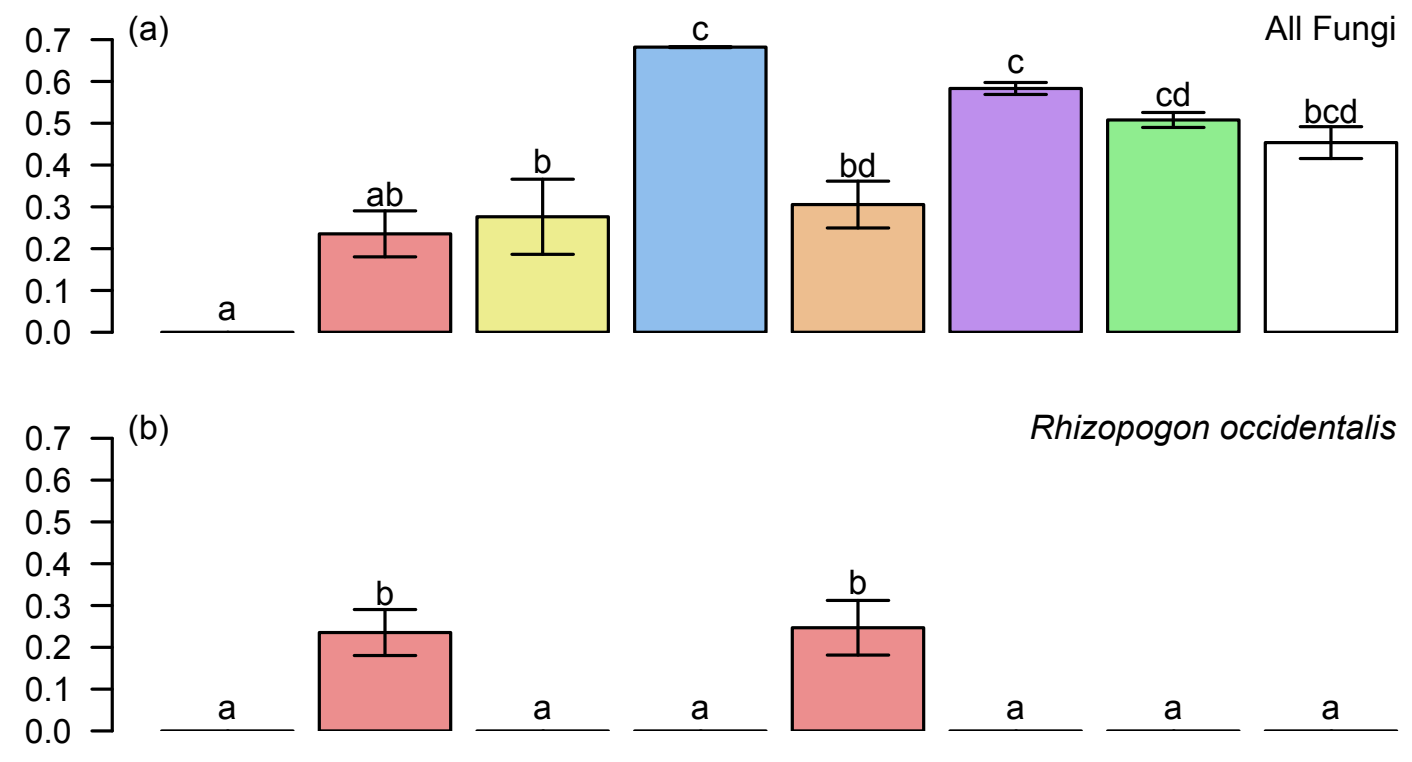

Suillus pungens

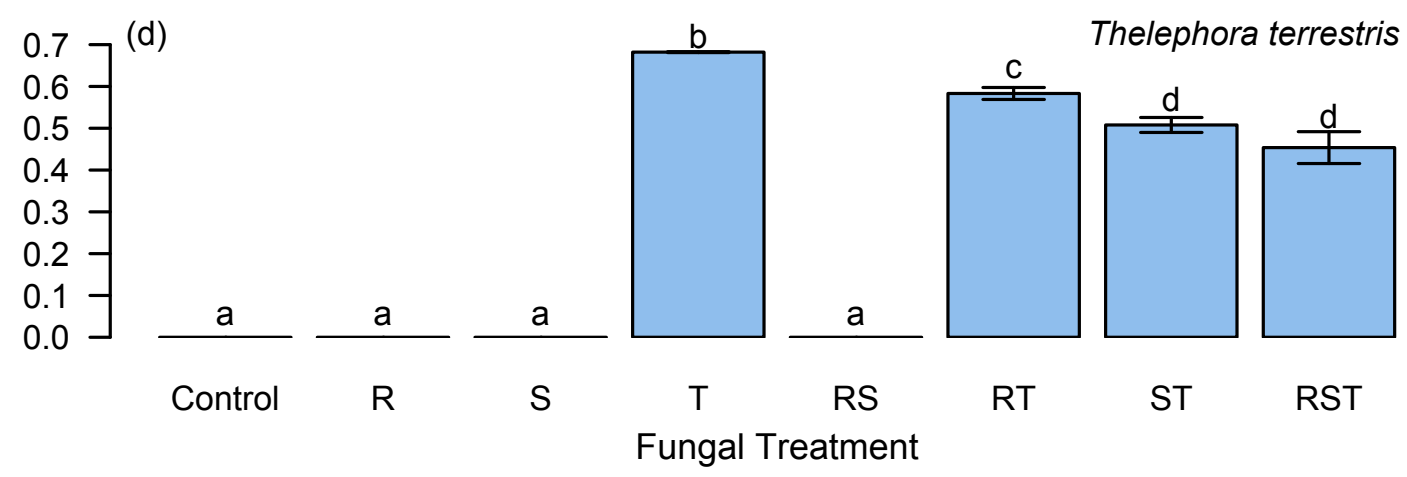

468 Figure 1. Mycorrhization levels across experimental treatments. Panel a: Total mycorrhization was highest in treatments that included Thelephora terrestris. No fungal contamination was

470 present in the controls. Panels b-c: Fungi exhibited a dominance hierarchy, with T. terrestris as the only fungus present in multi-species treatments, and Rhizopogon occidentalis suppressing

472 Suillus pungens growth in the two-species combination treatment. Bar heights indicate means across seedlings within a treatment group; whiskers give standard error. Letters indicate

474 statistically significant differences in mean (Tukey's HSD, $P<0.05$ ). Colors represent species: Red $=R$. occidentalis, yellow $=S$. pungens, and blue $=T$. terrestris; color blends represent

476 species combinations (e.g., green $=S$. pungens + T. terrestris in panel a, where total mycorrhization is plotted). 

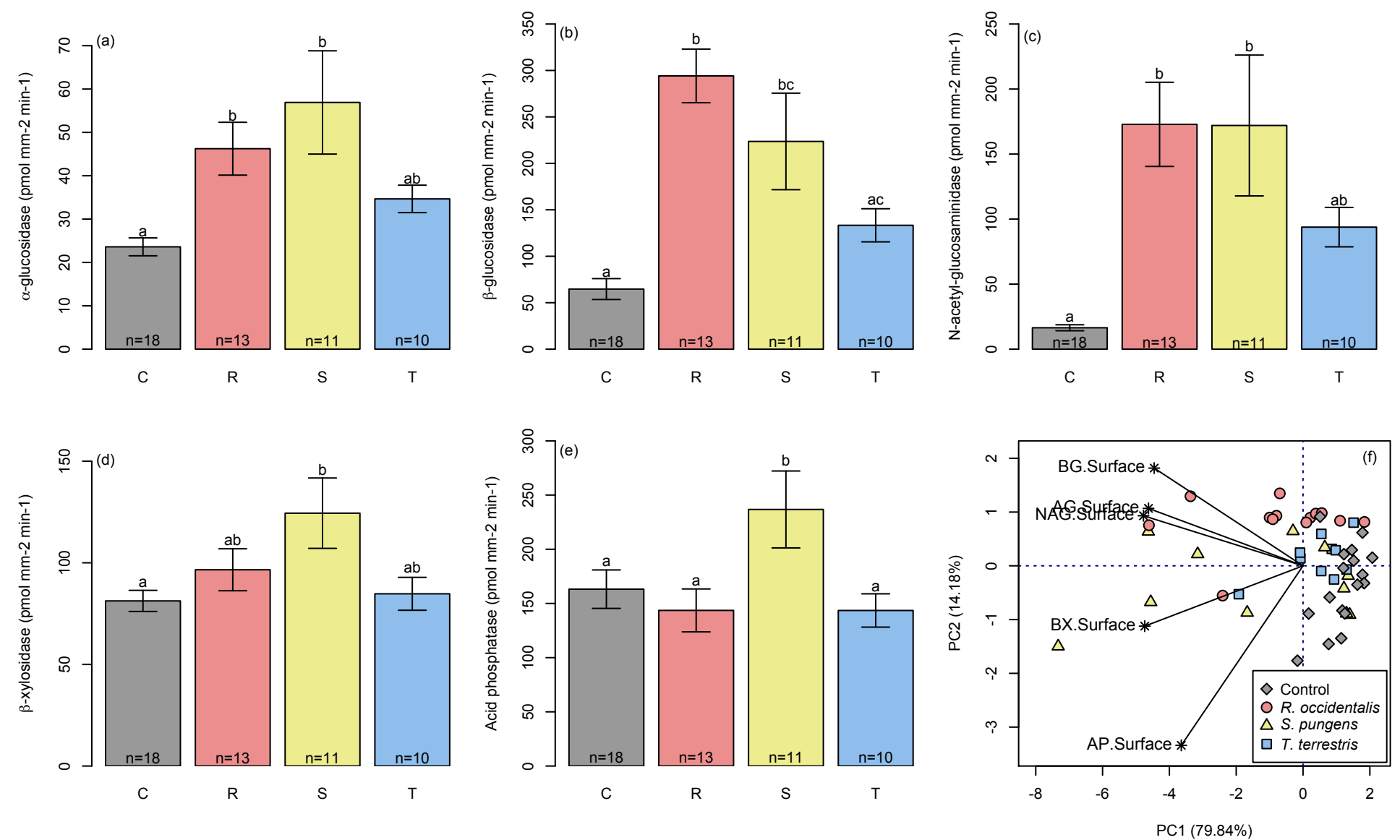

Figure 2. Enzyme activities of root tips colonized by the three fungal taxa compared with control (non-mycorrhizal) root tips. Data are from single-fungus inoculations (i.e., Treatment $=\mathrm{R}, \mathrm{S}$, or T). Across the five enzymes tested, only Suillus pungens-associated root tips showed consistently elevated activity relative to nonmycorrhizal tips (panels a-e; Tukey's HSD, $P<0.05$ ). Association with Rhizopogon occidentalis elevated $\alpha$ - and $\beta$-glucosidase and $\mathrm{N}$-acetyl-glucosaminidase enzyme activities relative to control tips. A principal component analysis (panel $\mathrm{f}$ ) revealed that fungi differed in their enzymatic assays (PERMANOVA, $P<0.05$ ). 


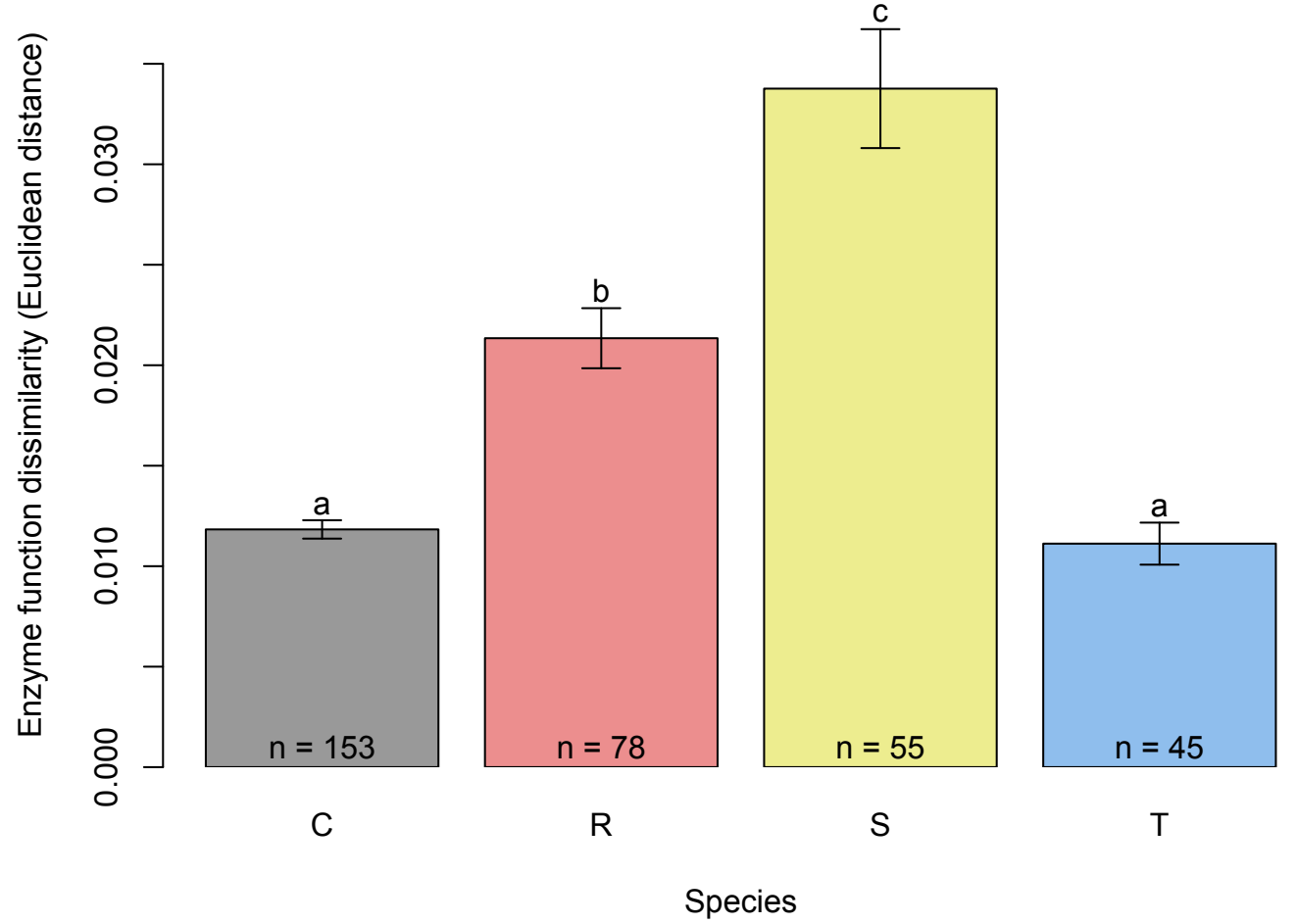

Figure 3. Variance in fungal enzymatic activity by species measured as Euclidean distance across all five enzymatic assays. Data are from single-fungus inoculations (as in Figure 2). S. pungens had the greatest variation in enzymatic function, $R$. occidentalis intermediate, and T. terrestris the least (Tukey's HSD, $P<0.05$ ). 

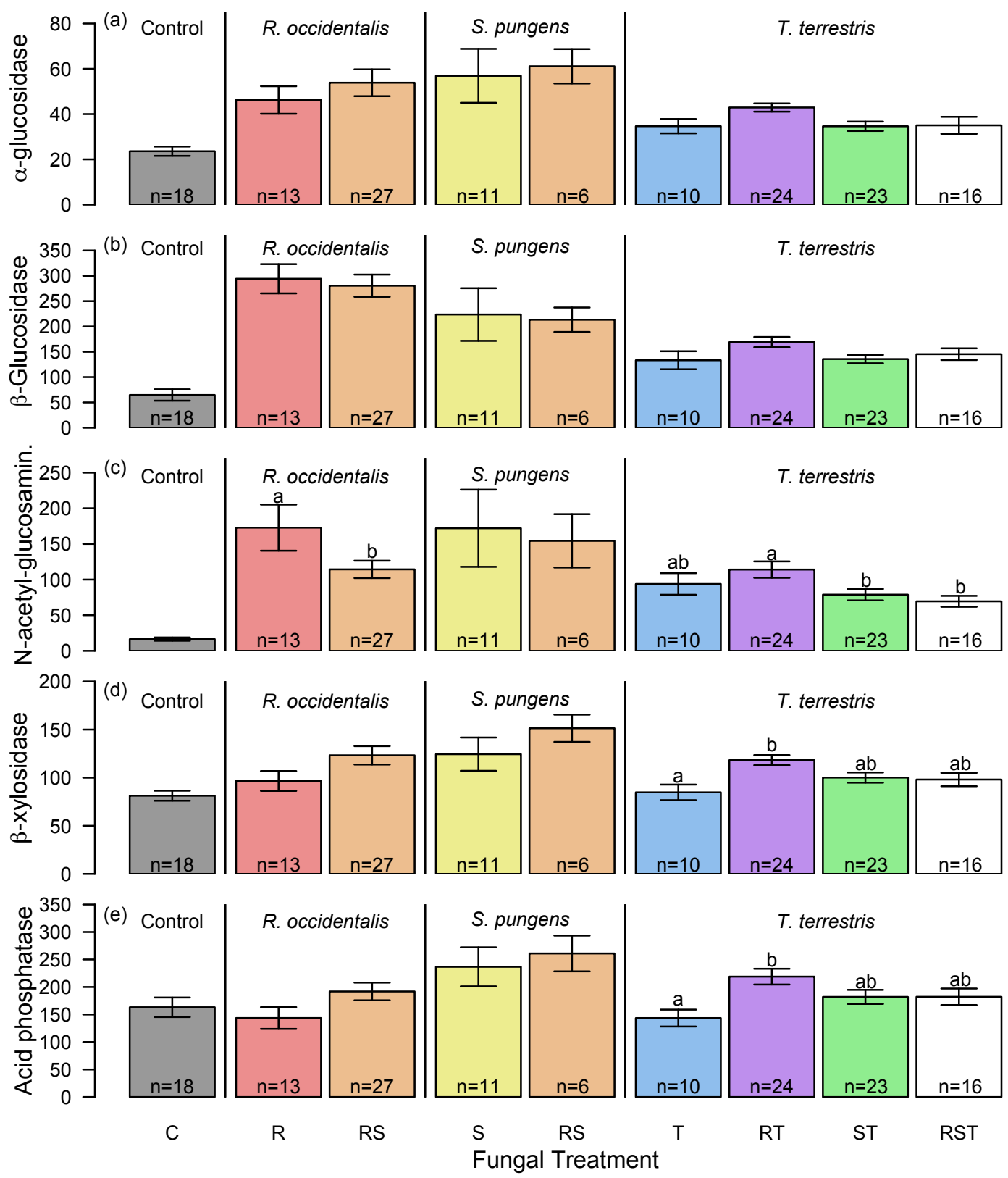

Figure 4. Changes in enzyme activity by fungal associate and treatment. N-acetylglucosaminidase activity was elevated for Rhizopogon occidentalis-associated root tips when in isolation relative to competition with Suillus pungens (panel c). $\beta$-xylosidase and acid phosphatase activities were elevated for Thelephora terrestris-associated tips when in competition with $R$. occidentalis (panels d-e). Bar heights indicate means across root tips within a treatment group (measured in pmol $\mathrm{mm}^{-2} \mathrm{~min}^{-1}$ ); whiskers give standard error. Letters indicate statistically significant differences in mean within species by treatment (Tukey's HSD, $P<0.05$ ). Colors represent treatments: Red $=R$. occidentalis, yellow $=S$. pungens, and blue $=T$. terrestris; color blends represent species combinations (e.g. green $=S$. pungens $+T$. terrestris). 


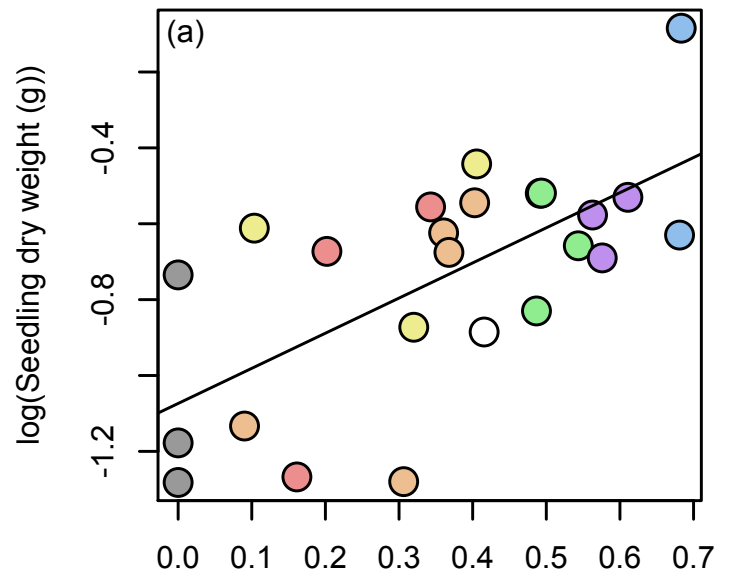

Prop. root length mycorrhizal

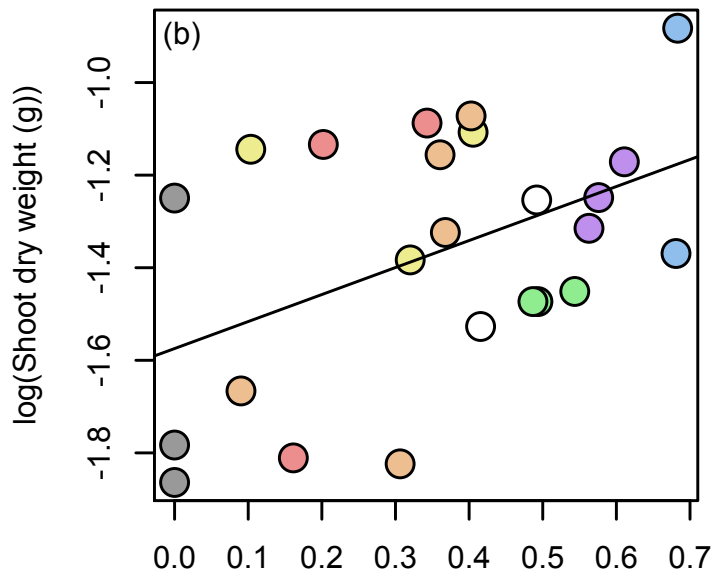

Prop. root length mycorrhizal

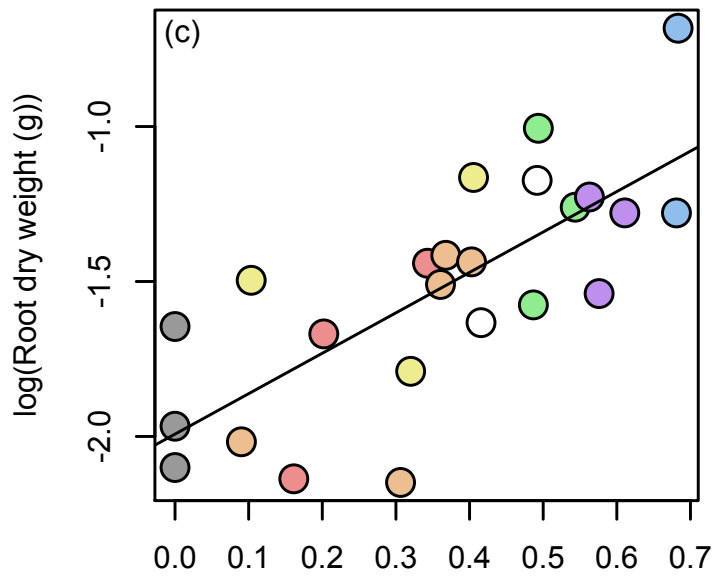

Prop. root length mycorrhizal

Figure 5. Relationship between seedling growth and mycorrhization level. Overall, total seedling biomass was positively correlated with mycorrhization, measured as the proportion of root length with hyphal structures (panel a, $\mathrm{R}^{2}=0.433, P<0.001$ ). This was the result of both above- and belowground effects of mycorrhization on plant growth: both shoot (panel $\mathrm{b}, \mathrm{R}^{2}=0.213, P<0.05$ ) and root (panel c, $\mathrm{R}^{2}=0.558, P<0.001$ ) dry weight increased with increasing mycorrhization. Points are color-coded by treatment as in Figs. $1-3$. 

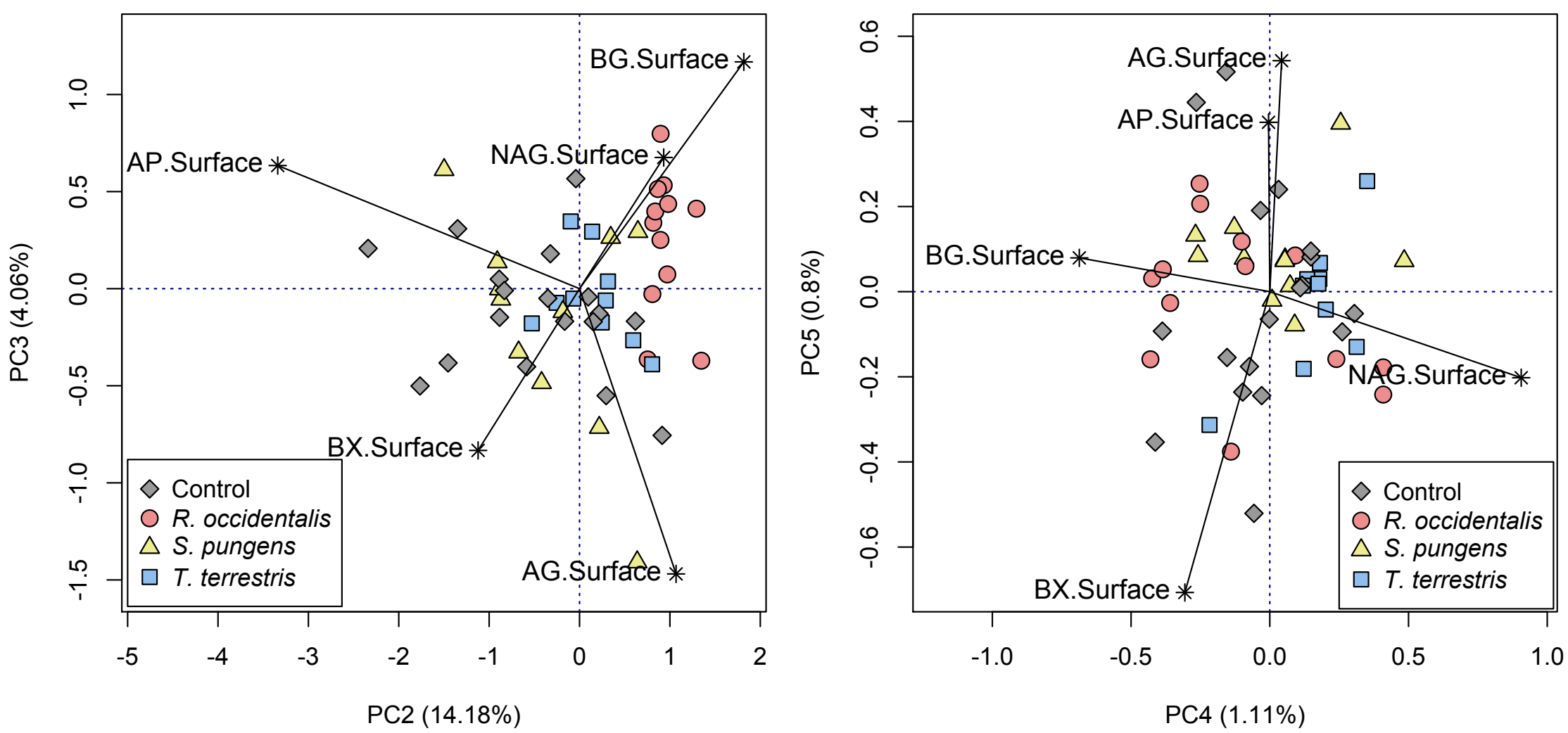

Supplemental Figure 1. Relationship between enzymatic activities of single-species treatment root tips (color and shape coded by species) and higher order principal component axes. Axis loadings are given in Table 1. 